\title{
Coombs test positivity in cord blood: early detection of risky newborns and the assessment of their follow-up results
}

\author{
Ali Ulaş Tuğcu' (iD), Faika Ceylan Çiftçi ${ }^{2}$ (D) , Esra Aktepe Keskin ${ }^{3}$ \\ ${ }^{1}$ Neonatology Clinic, Medisis Hospital, Yenidoğan Ankara, Turkey \\ ${ }^{2}$ Obstetrics \& Gynecology Clinic, Koru Hospital, Ankara, Turkey \\ Obstetrics \& Gynecology Clinic, Medisis Hospital, Ankara, Turkey
}

\begin{abstract}
Objective: Direct Coombs test (DCT) is a screening process to detect antibodies which are produced against the antigens in the red blood cells of newborns and cause hemolytic disease. In our study, we aimed to compare the demographic data and early period outcomes of the newborns with and without DCT positivity.

Methods: The data of all newborns who were born in our hospital between January 2019 and September 2019, of whose mothers gave informed consent before the labor and whose cord blood samples were examined were reviewed retrospectively. The data were analyzed by using SPPS 25 (IBM Corp. Released 2017; IBM SPSS Statistics for Windows, Version 25.0; IBM Corp., Armonk, NY, USA) statistics software.

Results: A total of 302 newborns were included in the study. The results of Direct Coombs test were positive in 27 cases. The phototherapy rate of the cases with positive DCT results was $74 \%$ (20/27). It was found that the cases with positive DCT results underwent more phototherapy, started to undergo phototherapy earlier, were hospitalized longer and had lower serum total bilirubin levels compared to the cases with negative DCT results, and these differences were statistically significant $(\mathrm{p}=0.003, \mathrm{p}=0.015, \mathrm{p}=0.038$ and $\mathrm{p}=0.026$, respectively).

Conclusion: Today, there is no specific method to prevent jaundice particularly for the newborns with a risk factor. The only thing to do for newborns at this point is to detect if they have risk factors or not, and to follow up newborns with risk factors appropriately. Direct Coombs test has still been playing an important role to predict hemolytic anemia and potential manifestation of hyperbilirubinemia in association with hemolytic anemia in the newborns, and to initiate treatment process as soon as possible.
\end{abstract}

Keywords: Direct Coombs test, hyperbilirubinemia, hemolytic anemia.

\section{Özet: Kord kanında Coombs testi pozitifliği: Riskli yenidoğanların erken saptanması ve izlem sonuçlarının değerlendirilmesi}

Amaç: Direkt Coombs testi (DCT), yenidoğanların kırmızı kürelerinde bulunan antijenlere karşı oluşan ve hemolitik hastalığa yol açan antikorların tespiti için yapılan bir tarama işlemidir. Çalışmamız, DCT pozitifliği olan ve olmayan yenidoğanların demografik verilerinin ve erken dönem sonuçlarının karşılaştırılması amaçlanmıştır.

Yöntem: Ocak 2019 ile Eylül 2019 tarihleri arasında hastanemizde doğan, doğum öncesinde annelerinden bilgilendirilmiş onam formu alınan ve kordon kanı çalışılan tüm yenidoğanların bilgileri geriye dönük olarak tarandı. Verilerin değerlendirilmesinde SPPS 25 (IBM Corp. Released 2017; IBM SPSS Statistics for Windows, Versiyon 25.0; IBM Corp., Armonk, NY, ABD) istatistik paket programi kullanildı.

Bulgular: Çalışmaya 302 yenidoğan dahil edildi. Direkt Coombs testi sonucu, 27 olguda pozitif saptandi. Direkt Coombs testi pozitifliği olan vakaların fototerapi oranları \%74 (20/27) bulundu. Direkt Coombs testi pozitif olguların, negatif olgulara göre istatistiksel olarak anlamlı şekilde daha fazla fototerapi aldı $\breve{g} 1$, daha erken fototerapi başlandı $\breve{g} 1$, hastanede daha uzun süre yattığı ve daha düşük serum total bilirubin değerleri olduğu tespit edildi (sırasıyla $\mathrm{p}=0.003, \mathrm{p}=0.015, \mathrm{p}=0.038$ ve $\mathrm{p}=0.026$ ).

Sonuç: Günümüzde sarılığın önlenmesi için özellikle risk faktörü olan yenidoğanlarda kesin bir yöntem bulunmamaktadır. Yenidoğanlar için bu noktada yapılabilecek olan, risk faktörüne sahip olup olmadığının tespiti ve risk faktörü saptanan yenidoğanların uygun şekilde izlemidir. Direkt Coombs testi, yenidoğanlarda hemolitik anemi ve buna bağlı gelişebilecek hiperbilirubinemi klinik tablosunun önceden öngörülebilmesinde ve gecikme olmadan tedavi sürecinin başlanabilmesinde, halen önemli rol oynamaktadır.

Anahtar sözcükler: Direkt Coombs testi, hiperbilirubinemi, hemolitik anemi.

Correspondence: Ali Ulaş Tuğcu, MD. Neonatology Clinic, Medisis Hospital, Yenidoğan Ankara, Turkey.

e-mail: ulastugcu@yahoo.co.uk / Received: January 25, 2020; Accepted: April 10, 2020

Please cite this article as: Tuğcu AU, Çiftçi FC, Aktepe Keskin E. Coombs test positivity in cord blood: early detection of risky newborns and the assessment of their follow-up results. Perinatal Journal 2020;28(1):42-47. doi:10.2399/prn.20.0281009 


\section{Introduction}

Direct antiglobulin test, which is also known as Direct Coombs test (DCT), is a screening process to detect antibodies which are produced against the antigens in the red blood cells (RBC) of newborns and cause hemolytic disease. These antibodies pass to the fetus from the immunoglobulin $\mathrm{G}$ ( $\mathrm{IgG}$ ) structure in the maternal serum transplacentally, and attach to the antigens on RBCs. Then, the deterioration process starts, which may lead to shortening the lifetime of RBCs of newborn, deterioration of RBCs, and severe anemia and hyperbilirubinemia. ${ }^{[1]}$

The reason causing DCT positivity in the newborns is mostly the $\mathrm{ABO}$ incompatibility between mother and fetus and/or newborn. In addition, Rh group incompatibilities, incompatibilities among small and sub-groups (anti-E, anti-C, etc.) and the presence of autoimmune hemolytic disease in mother may also cause DCT positivity. ${ }^{[2,3]}$ In our study, we aimed to compare the demographic data and early period outcomes of the newborns with and without direct antiglobulin test positivity.

\section{Methods}

The study was conducted as a retrospective review of the data of all newborns who were born in Obstetrics \& Gynecology Clinic of Medisis Hospital between January 2019 and September 2019, of whose mothers gave informed consent before the labor and whose cord blood samples were examined. The preterm newborns whose week of gestation was $<36$, and the term newborns diagnosed with sepsis, congenital malformation, chromosomal anomaly and congenital heart disease were excluded from the study.

Cord bloods were collected during labor by $5 \mathrm{ml}$ sterile injector, and the obtained samples were studied by hemagglutination and antiglobulin antibody assay for blood type and Rh determination and gel centrifugation / colon agglutination method for Direct Coombs test via DiaMED-ID Micro Typing System ${ }^{\circledR}$ (Diamed, Morat, Switzerland) in the blood bank. Direct antiglobulin results were classified as negative, $+1,+2,+3$ and +4 .

The blood bank data of the patients who gave informed consents were reviewed, and blood types and $\mathrm{Rh} \mathrm{D}$ groups of mothers and newborns, antibody assays if mothers had alloimmunization, the direct antiglobulin test results and the grades of those whose tests were pos- itive were recorded. The antenatal and postnatal period characteristics of the newborns, whose direct antiglobulin tests were normal, were reviewed via the hospital databank. The antenatal, natal and postnatal records of the newborns, whose direct antiglobulin tests were negative and underwent phototherapy with the preliminary diagnosis of indirect hyperbilirubinemia, were reviewed. The maternal age, gestational diabetes, maternal infection during pregnancy, and the presence or absence of maternal alloimmunization and fetal hydrops were recorded in the both groups. The data of birth weights and sexes of newborns, week of gestation, delivery type (normal spontaneous vaginal delivery [NSVD] or cesarean section [C/S]), nourishment method (only breastfeeding, only formula, both breastfeeding and formula), anemia, polycythemia, cephalohematoma and ecchymosis were recorded. The presence of hemolysis was confirmed by peripheral smear and reticulocyte count. It was noted down that whether phototherapy was performed or not, its duration (hour) if performed, serum bilirubin level when the phototherapy was initiated, whether a second hospitalization was carried out or not due to elevated bilirubin level, whether blood transfusion was conducted or not, and whether intravenous immunoglobulin (IVIG) treatment was done or not. ABO incompatibility between mother and newborn was defined as the condition where the blood type of mother was 0 while it was $\mathrm{A}, \mathrm{B}$ or $\mathrm{AB}$ for the newborn.

Phototherapy decision was made according to the 2004 and 2011 (revised) guidelines of the American Academy of Pediatrics. ${ }^{[4]}$ Follow-up of the bilirubin levels of the newborns who were decided to receive treatment, discharge decision and check-up time for discharged newborns were decided by the same physician via the hour-specific Bhutani nomogram. ${ }^{[5]}$ The demographic data and early period outcomes of the newborns with and without the direct antiglobulin test positivity were compared. SPPS 25 (IBM Corp. Released 2017; IBM SPSS Statistics for Windows, Version 25.0; Armonk, NY, USA) statistics software was used to evaluate the data. The variables were presented as mean \pm standard deviation, percentage and frequency. The variables were evaluated after checking the normality and variance homogeneity preconditions (ShapiroWilk and Levene's tests). Kolmogorov-Smirnov test was performed to identify whether or not parameters are normally distributed. Student's t-test and MannWhitney $U$ test were used for the comparison between 
two groups. The categorical data were analyzed by Fisher's exact test and Chi-square test. $\mathrm{p}<0.05$ was considered statistically significant in the tests.

\section{Results}

A total of 302 newborns were born during the study period. Of the infants, the blood type was A in 132 (43.7\%), $\mathrm{B}$ in 47 (15.5\%), 0 in 102 (33.7\%), and $\mathrm{AB}$ in 21 (6.9\%). There was $\mathrm{ABO}$ incompatibility between mother and newborn in $64(21.1 \%)$ cases (53 newborns with the blood type of A, and 11 newborns with the blood type of B). Rh incompatibility was found in 4 cases. The result of direct Coombs test was positive in 27 cases. Of these cases, the test result was +1 in $18,+2$ in $8,+3$ in 1 , but no case with +4 was found. The phototherapy rates of the cases with positive result for the direct Coombs test was 74\% (20/27) (Table 1). Gestational diabetes, maternal infection during pregnancy, maternal alloimmunization and fetal hydrops were not observed in both groups. There was no statistically significant difference between the groups in terms of the week of gestation and birth weight ( $\mathrm{p}=0.445$ and $\mathrm{p}=0.280$, respectively).

It was found that the cases with positive result in the direct Coombs test underwent more phototherapy, the phototherapy was initiated earlier, they were hospitalized for a longer time and had lower levels of serum total bilirubin values in a statistically significant way compared to the cases with negative DCT result $(\mathrm{p}=0.003, \mathrm{p}=0.015$, $\mathrm{p}=0.038$ and $\mathrm{p}=0.026$, respectively). It was found that hemolysis and IVIG treatment were higher in the group with positive DCT and serum total bilirubin level, ecchymosis and polycythemia were higher in the group with negative DCT in a statistically significant way $(\mathrm{p}<0.05)$. No significant difference was found between the groups in terms of rehospitalization and nourishment method for phototherapy ( $>0.05$ ) (Table 1).

Direct Coombs test positivity was found in 27 (8.9\%) newborns. It was found that all of the cases with positive result had $\mathrm{ABO}$ incompatibility (the newborn was $\mathrm{A}$ and the mother was 0 in 21 cases, and the newborn was $B$ and the mother was 0 in 6 cases). Rh and minor blood type incompatibility was not detected in none of the newborns with positive Direct Coombs test. While 15 (55.6\%) of the cases were female, 12 (44.4\%) of them were male. Their mean weight was $3130 \pm 468 \mathrm{~g}$, and the mean week of gestation was $37.7 \pm 1.5$ weeks. It was found that 20 of the cases were delivered by C/S and 7 of them by NSVD. It was found that the total serum bilirubin levels of 11 newborns with positive direct Coombs test, who did not undergo phototherapy within the first 48 hours and discharged, were high enough to receive phototherapy.

Thirty-seven (13.4\%) newborns (37/275) with negative direct Coombs test underwent phototherapy. Of these cases, $19(51.3 \%)$ were female and 18 (48.7\%) were male. Their mean weight was $2980 \pm 516 \mathrm{~g}$, and mean

Table 1. The demographic and clinical characteristics of the groups.

\begin{tabular}{|c|c|c|c|c|c|c|}
\hline Demographic and clinical characteristics & $\begin{array}{c}\text { DCT positive } \\
n=27\end{array}$ & & & $\begin{array}{c}\text { DCT negative } \\
n=275\end{array}$ & & p-value \\
\hline Week of gestation (week) & $37.8 \pm 1.5$ & & & $37.4 \pm 1.8$ & & 0.445 \\
\hline Birth weight (g) & $3130 \pm 468$ & & & $2980 \pm 516$ & & 0.280 \\
\hline Cases who underwent phototherapy & $20(74 \%)$ & & & $37(13.4 \%)$ & & $0.003^{*}$ \\
\hline Hospitalization day (day) & $2.26 \pm 1.34$ & & & $5.34 \pm 1.12$ & & $0.015^{*}$ \\
\hline Hospitalization duration (hour) & $34.9 \pm 6.06$ & & & $27.9 \pm 9.06$ & & $0.038^{*}$ \\
\hline Serum bilirubin level at hospitalization $(\mathrm{mg} / \mathrm{dl})$ & $12.89 \pm 4.46$ & & & $18.45 \pm 2.78$ & & $0.026^{*}$ \\
\hline Second hospitalization & $2(7.4 \%)$ & & & $15(5.4 \%)$ & & 0.365 \\
\hline \multirow[t]{2}{*}{ Nourishment method } & $\begin{array}{l}\text { Breastfeeding } \\
\quad+\text { formula } \\
\end{array}$ & Formula & Breastfeeding & $\begin{array}{l}\text { Breastfeeding } \\
\quad+\text { formula }\end{array}$ & Formula & \\
\hline & $10(37 \%)$ & $2(7.4 \%)$ & $20(54 \%)$ & $14(37.8 \%)$ & $3(8.2 \%)$ & 0.235 \\
\hline Hemolysis & $5(18.5 \%)$ & & & 0 & & $0.01 *$ \\
\hline Ecchymosis & 0 & & & $4(1.4 \%)$ & & $0.02 *$ \\
\hline Polycythemia & 0 & & & $2(0.7 \%)$ & & $0.037 *$ \\
\hline Intravenous & $3(11.1 \%)$ & & & 0 & & $0.03^{*}$ \\
\hline
\end{tabular}

${ }^{*} \mathrm{p}<0.05$ was considered statistically significant. 
week of gestation was $37.4 \pm 1.8$ weeks. It was found that $25(67.6 \%)$ of the cases were delivered by C/S and 12 $(32.4 \%)$ of them by NSVD. The blood type was A in 18 (48.6\%) newborns, 0 in $11(29.7 \%)$ newborns, B in 6 $(16.2 \%)$ newborns and $\mathrm{AB}$ in $2(5.4 \%)$ newborns. $\mathrm{ABO}$ incompatibility was detected in 14 newborns who had negative direct Coombs test and underwent phototherapy ( $\mathrm{A}$ in newborns and 0 in mothers in 12 cases, and $\mathrm{B}$ in newborns and 0 in mothers in 2 cases) while 4 newborns had $\mathrm{Rh}$ incompatibility and negative DCT. Minor blood type incompatibility was not observed in none of our cases. Of the cases, 4 (14.8\%) had ecchymosis (history of difficult labor) and 2 (7.4\%) had polycythemia (newborn polycythemia). It was found that the siblings of three cases underwent phototherapy upon the preliminary diagnosis of indirect hyperbilirubinemia.

\section{Discussion}

It is known that the indirect hyperbilirubinemia which is not diagnosed early and on time and treated properly leads to various early and late (kernicterus) neurological sequels and bilirubin encephalopathy in particular. ${ }^{[6,7]}$ therefore, early detection of elevated bilirubin and starting treatment process early are important. In our study, we aimed to investigate how carrying out direct Coombs test on all newborns routinely and conducting close clinical follow-up on the newborns with positive and negative test results affect the outcomes.

For the decision on who will undergo DCT in cord blood, hyperbilirubinemia sub-committee recommends testing all pregnant women in terms of $\mathrm{ABO}$ and $\mathrm{Rh}(\mathrm{D})$ groups, screening in terms of potential antibodies seen rarely, (i) conducting blood type test, $\mathrm{Rh}$ assay and direct Coombs test on cord blood if blood type of pregnant woman is not known during prenatal period or if it is $\mathrm{Rh}$ (-), (ii) deciding to perform blood type test and DCT on cord blood by considering the risk factors. ${ }^{[4]}$

As required by our hospital policy, we carry out blood type test and DCT on the cord blood of all newborns. Various studies showed that carrying out DCT on the cord blood of the newborns with $\mathrm{ABO}$ and $\mathrm{Rh}$ incompatibilities help to detect potential hemolysis and its complications early. ${ }^{[8,9]}$ There are also studies showing that detecting and following up bilirubin level in the cord blood predict hyperbilirubinemia development better but carrying out DCT on the cord blood routinely is not helpful in terms of cost-efficiency. ${ }^{[10,11]}$
Our study found DCT positivity in $8.9 \%$ of all newborns born in our hospital. This is above the rates reported by the various studies in the literature. Diloon et al. found this incidence $2.3 \%$ while Valsami et al. reported it $2.59 \% .^{[12,13]}$ This rate was $6.6 \%$ in the study of Altuntaş et al., and it was similar with the rate we found in our study. ${ }^{[14]}$

$\mathrm{ABO}$ incompatibility is the most common reason for the hemolytic disease of the newborn. Of all pregnancies, $15-20 \%$ have $\mathrm{ABO}$ incompatibility. ${ }^{[15]}$ The rate of $\mathrm{ABO}$ incompatibility was $21.1 \%$ in our study. Together with $\mathrm{Rh}$ immunization, minor blood type incompatibilities have become one of the most important reasons of the hemolytic disease of the newborn. In our study, we did not detect any minor blood type incompatibility in the groups. Narter et al. found that $38.1 \%$ of the cases with DCT positivity developed hyperbilirubinemia that needs treatment, this rate was $74 \%$ in our study. ${ }^{[16]}$

In our study, all newborns with positive DCT were followed-up closely by the same physician in terms of hyperbilirubinemia, serum bilirubin levels were checked in the newborns with apparent kernicterus. Accordingly, serum bilirubin levels were over 95 percentile by the age in 16 of 27 newborns with positive DCT within the first 48 hours according to the bilirubin nomogram and they started to undergo phototherapy. We reevaluated eleven newborns, who had Coombs test positivity and did not undergo phototherapy in the first 48 hours, within the first 24-48 hours after the discharge in accordance with the directive, and we found that the serum total bilirubin values were at a level that requires phototherapy in 4 of 11 newborns. We believe that the higher hyperbilirubinemia rate that requires treatment in our study than other studies is because we followed up risk group more closely and systematically, and this showed that the patients with positive DCT should be followed up more closely.

It is known that the serum bilirubin level of newborns reaches to the peak level at 3rd-6th days. ${ }^{[17]}$ Therefore, it is recommended calling the cases, who are discharged early after the delivery and in the risk group in terms of hyperbilirubinemia, for check-up within 24-48 hours after discharge.$^{[18]}$ In our hospital, we carry out postnatal follow-up of mothers and newborns in 48 hours. We ask families to bring their infants for followup within 24-48 hours after evaluating the risk factors.

Direct Coombs test is a very useful examination to predict when indirect hyperbilirubinemia reaches 
pathological threshold and hospitalization for phototherapy. ${ }^{[14]}$ Therefore, the test being positive makes clinicians be more cautious in terms of the potential clinical conditions (hemolytic anemia) and their complications (hyperbilirubinemia, hydrops, heart failure etc.). In terms of the newborns who are not in the risk group, delays may occur in the diagnosis and treatment processes. In line with this, the day of initiating phototherapy was earlier and phototherapy duration was shorter in the cases with positive DCT compared to the cases with negative DCT. Hospitalization bilirubin threshold for phototherapy was shorter in the cases with positive DCT who were hospitalized earlier was shorter due to the presence of risk factors.

The rates of indirect hyperbilirubinemia risk factors (ABO and $\mathrm{Rh}$ incompatibility, ecchymosis, polycythemia, the history of sibling which underwent phototherapy) in the cases with negative DCT are similar with the previous studies (in this group, only the routine physical examination was performed for icterus in the postnatal 48-hour follow-up period beside their mothers). ${ }^{[19]}$

In terms of the limitations of our study, it is unclear if the newborns which were born in our hospital underwent phototherapy in another center with the diagnosis of indirect hyperbilirubinemia except the newborns in our study which underwent phototherapy. Since knowing these data may affect the results of our study, our study has the limitation of being single-centered. Our data cannot be generalized as they are the results of a single-centered study. Therefore, it is needed to evaluate the risk factors associated with national phototherapy through detailed and larger samples.

\section{Conclusion}

Today, there is no specific method to prevent jaundice particularly for the newborns with a risk factor. The only thing to do for newborns at this point is to detect if they have risk factors or not, and to follow up newborns with risk factors appropriately. Direct Coombs test has still been playing an important role to predict hemolytic anemia and potential manifestation of hyperbilirubinemia in association with hemolytic anemia in the newborns, and to initiate treatment process as soon as possible.

Conflicts of Interest: No conflicts declared.

\section{References}

1. Issitt PD. Hemolytic disease of the newborn. In: Issitt PD, editor. Applied blood group serology. 3rd ed. Durham, NC: Montgomery Scientific, 1985. p. 571-98.

2. Tugcu AU. Ince DA, Turan O, Belen B, Olcay L, Ecevit A. Hemolytic anemia caused by non-D minor blood incompatibilities in a newborn. Pan Afr Med J 2019;33:262.

3. Moran P, Robson SC, Reid MM. Anti-E in pregnancy. BJOG 2000;107:1436-8.

4. American Academy of Pediatrics Subcommittee on Hyperbilirubinemia. Management of hyperbilirubinemia in the newborn infant 35 or more weeks of gestation. Pediatrics 2004;114:297-316.

5. Bhutani VK, Johnson L, Sivieri EM. Predictive ability of a predischarge hour-specific serum bilirubin for subsequent significant hyperbilirubinemia in healthy term and near-term newborns. Pediatrics 1999;103:6-14.

6. deHaas M, Thurik FF, Koelewijn JM, van der Schoot CE. Haemolytic disease of the fetus and newborn. Vox Sang 2015; 109:99-113.

7. Kaplan M, Bromiker R, Hammerman C. Hyperbilirubinemia, hemolysis, and increased bilirubin neurotoxicity. Semin Perinatol 2014;38:429-37.

8. Baptista-González H, Hernández-Martínez JA, GalindoDelgado P, Santamaría-Hernández C, Rosenfeld-Mann F. Usefulness of direct antiglobulin test in neonatal screening. [Article in Spanish] Bol Med Hosp Infant Mex 2009;66:50210.

9. Kaplan M, Hammerman C, Vreman HJ, Wong RJ, Stevenson DK. Direct antiglobulin titer strength and hyperbilirubinemia. Pediatrics 2014;134:e1340-4.

10. Shahid R, Graba S. Outcome and cost analysis of implementing selective Coombs testing in the newborn nursery. J Perinatol 2012;32:966-9.

11. Leistikow EA, Collin MF, Savastano GD, de Sierra TM, Leistikow BN. Wasted health care dollars. Routine cord blood type and Coombs' testing. Arch Pediatr Adolesc Med 1995;149: 1147-51.

12. Dillon A, Chaudhari T, Crispin P, Shadbolt B, Kent A. Has anti-D prophylaxis increased the rate of positive direct antiglobulin test results and can the direct antiglobulin test predict need for phototherapy in $\mathrm{Rh} / \mathrm{ABO}$ incompatibility? J Paediatr Child Health 2011;47:40-3.

13. Valsami S, Politou M, Boutsikou T, Briana D, Papatesta M, Malamitsi-Puchner A. Importance of direct antiglobulin test (DAT) in cord blood: causes of DAT (+) in a cohort study. Pediatr Neonatol 2015;56:256-60.

14. Altuntaş N, Taşçı Çelebi D, Koçak M, Andıran N. Yenidoğan bebeklerde direkt Coombs testi taraması ve pozitifliğinin morbidite üzerine etkisi; tek merkez deneyimi. Pamukkale Tip Dergisi 2015;8:39-44. 
15. Sarici SU, Yurdakök M, Serdar MA, Oran O, Erdem G, Tekinalp G, et al. An early (sixth-hour) serum bilirubin measurement is useful in predicting the development of significant hyperbilirubinemia and severe $\mathrm{ABO}$ hemolytic disease in a selective high-risk population of newborns with $\mathrm{ABO}$ incompatibility. Pediatrics 2002;109:e-53.

16. Narter F, Ergüven M. Direkt Coombs pozitif ABO uygunsuzluğunda doğum sonrası on ikinci saatte bilirubin persentilinin profilaktik intravenöz immünglobülin kullanımında belirleyici rolü. Çocuk Dergisi 2009;9:22-4.
17. Maisels MJ, Newman TB. Jaundice in full-term and near-term babies who leave the hospital within 36 hours. The pediatrician's nemesis. Clin Perinatol 1998;25:295-302.

18. Braveman P, Egerter S, Pearl M, Marchi K, Miller C. Problems associated with early discharge of newborn infants. Early discharge of newborns and mothers: a critical review of the literature. Pediatrics 1995;96:716-26.

19. Bratlid D. Bilirubin toxicity: pathophysiology and assessment of risk factors. N Y State J Med 1991;91:489-92.

Bu makalenin kullanım izni Creative Commons Attribution-NoCommercial-NoDerivs 3.0 Unported (CC BY-NC-ND3.0) lisansı aracılı̆̆ıly bedelsiz sunulmaktadir. / This work is licensed under the Creative Commons Attribution-NonCommercial-NoDerivs 3.0 Unported (CC BY-NC-ND3.0) License. To view a copy of this license, visit http://creativecommons.org/licenses/by-nc-nd/3.0/ or send a letter to Creative Commons, PO Box 1866 , Mountain View, CA 94042, USA. 